KRETZ, R. 1961a. Coexisting pyroxenes. Geol. Mag., 98, 344-5.

- $1961 \mathrm{~b}$. Some applications of thermodynamics to coexisting minerals of variable composition. Examples: orthopyroxene-clinopyroxene and orthopyroxenegarnet. J. Geol., 69, 361-387.

LEELANANDAM, C. 1967. Chemical study of pyroxenes from the charnockitic rocks of Kondapalli (Andhra Pradish), India, with emphasis on the distribution of elements in coexisting pyroxenes. Miner. Mag., 36, 153-179.

WILSON, A. F. 1960. Coexisting pyroxenes: Some causes of variation and anomalies in the optically derived compositional tie-lines, with particular reference to charnockitic rocks. Geol. Mag., 97, 1-17.

\author{
DEPARTMENT OF GEOLOGY, \\ UNIVERSITY OF OTTAWA, \\ OTTAWA 2, ONTARIO, \\ CANADA. \\ 15th January, 1969.
}

K. R. CHAKRABORTY.

\title{
STRATIGRAPHICAL SUB-DIVISIONS OF THE SKIDDAW SLATES OF THE LAKE DISTRICT
}

SIR,-In the chapter on the Skiddaw Slates in the recently-published Memoir of the Geological Survey of Great Britain (The Geology of the Country around Cockermouth, Eastwood and others, 1969), a comparison is made. in Figure 4 between the sequence in the Skiddaw Slates for the district under description and that in the ground to the south around Keswick and Buttermere, the latter after Rose (1954) and Jackson (1961). Much of the sequence shown for the latter area agrees with that put forward by the writer in a summarized account (The Geology of the Lake District by S. E. Hollingworth and others, 1954) of work which involved detailed mapping on the six-inch scale of the whole of this area (the full results of this work are not yet published). It is not made clear in the recent memoir, however, that the term "Hope Beck Slates" used in the section in Figure 4 should be ascribed wholly to Jackson.

The term "Hope Beck Slates" was introduced by Jackson (1961) to denote a distinct formation of slates claimed by him to underlie the Loweswater Flags and to outcrop in an area south-east of Lorton on the northern and western flanks of Dodd and near Scaw Gill. The detailed work by the writer, however, does not confirm the existence of a discrete group of slates in this stratigraphical position. The new palaeontological evidence obtained by Jackson (1962) does no more in this connection than confirm the existence of the lowest fauna (Didymograptus deflexus) so far recognized beyond doubt in the Skiddaw Slates (both in this area and in the ground covered by the Cockermouth Memoir) as being present at Scaw Gill. The only evidence of the possible presence of a lower zone in the ground southeast of Lorton is the provisional assignment by Jackson (1964) of a single specimen to the Tetragraptus approximatus group. In the view of the writer, therefore, the grounds on which the term "Hope Beck Slates" have been introduced are insecure and the tetm should not be retained.

Generally over the Keswick-Buttermere area the writer believes that on stratigraphical grounds the lowest rocks exposed are probably arenaceous and gritty beds, forming the lower part of the Loweswater Flags. As yet, however, palaeontological evidence is lacking. These beds do include some coarse grits and can probably be correlated with the "Grit" group, the lowest of the subdivisions proposed in the Cockermouth Memoir. The general conclusions of the writer from his work in the Keswick-Buttermere area agree closely with those reached by the Geological Survey in the Cockermouth area; they do not support the subdivision of the Skiddaw Slates recently put forward by Simpson (1967).

\section{REFERENCES}

EASTWOOD, T., HOLLINGWORTH, S. E., ROSE, W. C. C. \& TROTTER, F. M. 1969. The Geology of the country around Cockermouth. Mem. Geol. Surv. U.K. 
JACKSON, D. E. 1961. The Stratigraphy of the Skiddaw Group between Buttermere and Mungrisdale, Cumberland. Geol. Mag., 98, 512-528.

1962. Graptolite Zones in the Skiddaw Group in Cumberland, England. J. Palaeont., 36, 300-313.

1964. Observations on the sequence and correlation of the Lower and Middle Ordovician graptolite faunas of North America. Bull. geol. Soc. Am., 75, $523-534$.

ROSE, W. C. C. 1954. The sequence and structure of the Skiddaw Slates in the Keswick-Buttermere area. Proc. Geol. Ass., 65, 403-406.

SIMPSON, A. 1967. The stratigraphy and tectonics of the Skiddaw Slates and the relationship of the overlying Borrowdale Volcanic Series in part of the Lake District. Geol. J., 5, 391-418.

\author{
INSTITUTE OF GEOLOGICAL SCIENCES, \\ LONDON, S.W.7. \\ 18th March, 1969.
}

W. C. C. ROSE

\title{
ESSAY REVIEW
}

\section{SHELL STRUCTURE OF ARTICULATE BRACHIOPODS \\ CHARLES HARPER, Jr.}

WILLIAMS, ALWYN. 1968. Evolution of the Shell Structure of Articulate Brachiopods. Special Papers in Palaeontology No.2., 55 p., 27 figs., 24 pls. The Palaeontological Association, London. Price £5; U.S. \$13.

Williams' paper presents much new data in the way of electron micrographs of selected brachiopod species together with some interesting speculations as to the relationship of the shell to the soft anatomy, mechanisms of shell secretion, and the evolution of brachiopod shell structure. Electron micrographs are illustrated for 8 species of the Order Terebratulida, 4 species of the Order Rhynchonellida, 10 species of the Order Spiriferida, 2 species of the Order Pentamerida, 10 species of the Order Strophomenida, and 8 species of the Order Orthida; typically two or three photographs are provided for each species. Other groups are discussed but their shell structure is not documented.

The work represents a significant contribution to our understanding of brachiopod shell structure, but the title and text are misleading in that they imply that Williams has made a comprehensive review of brachiopod shell structure. In actual fact, he presents data for only a few select species of each of the major brachiopod orders, orders which have ranges of hundreds of millions of years and include many genera and thousands of recognized species. Furthermore, if the work is indeed meant to be comprehensive, then the data should have been supported by light microscope photographs of thin sections as well as by scanning electron micrographs. (The latter omission is partially alleviated by a more recent paper (Williams, 1968) ). Williams (p. 1) himself states that "the most profitable techniques. . involve the preparation of replicas of the internal surfaces as well as sections. . .and their examination under the light microscope supplemented by the electron microscope" (italics mine). His conclusions regarding shell structure, however, are certainly better documented than those in his earlier papers (Williams 1953, 1956; Williams \& Rowell 1965) where he only illustrates the structures allegedly observed by line drawings. In a line drawing, it is impossible to separate validly documented structures from science fiction. Other workers must go back and repeat the work illustrated to establish its validity.

Any attempt to make generalizations about brachiopod shell structure on the basis of Williams' published data is, if not premature, at least highly speculative. That Williams' 